\title{
8. Analysis of a beat-up The structuring of a sensational media story
}

\begin{abstract}
Media beat-ups are sensationalised stories that greatly exaggerate or misrepresent the significance of otherwise unremarkable events or issues. To illustrate how beat-ups can be analysed, a front-page story in Sydney's Daily Telegraph newspaper is examined in terms of its venue, the journalist and the content of the story. The features of a beat-up may be less arbitrary than they appear on the surface.
\end{abstract}

Keywords: attack journalism, Australia, beat-up, Daily Telegraph, News Corp Australia, newspapers, sensationalism, tabloidisation, terrorism, trolling, yellow journalism

\section{BRIAN MARTIN \\ University of Wollongong}

\section{Introduction}

N 26 May 2017, the front page of Sydney’s Daily Telegraph, Australia’s second highest circulation newspaper, had a huge headline: 'THREAT LEVEL: HIVE' (Figure 1). The story (Loussikian, 2017), which covered most of pages 4 and 5 of the tabloid, was apparently triggered by a few sentences in the doctoral thesis of Aloysia Brooks (2016), a human rights campaigner and recent graduate (Figures 2, 3). She noted, in a passing comment, that more people died in Australia from bee stings than terrorists, yet there was no war on bees. The Telegraph story featured photos of her and her former husband, David Hicks, who had been one of two Australians imprisoned at Guantanamo Bay in the aftermath of the 9/11 attacks.

The story was unexpected. There had been no previous coverage of Brooks. Nor was there any follow-up on subsequent days. The story was a 'one-day wonder', apparently important at the time but of no lasting media significance. It stimulated commentary in several other newspapers (e.g., Bolt, 2017; Eddie, 2017), reliant on Loussikian's treatment, but without any independent investigation.

I had been the principal supervisor for Brooks' doctoral thesis and immediately recognised the tone and content of the Telegraph story as hostile towards Brooks. The story took a single passage out of context and made fun of it without any rationale. Readers of the story would have been hard pressed to realise that the focus of her thesis was Australian media coverage of torture in the war on terror. Seemingly unwittingly, the Telegraph story provided an additional example 
of the sort of media coverage examined in Brooks' thesis.

In Australian terminology, the story was a 'beat-up': treatment of an issue in a greatly exaggerated way, far beyond what would normally be considered newsworthy. A beat-up turns something that few would say is of any significance into something of seeming importance. Why should a peripheral comment about bees and terrorism in a doctoral thesis be considered newsworthy?

Because I had a personal interest in this story - it was a blatant attack on my $\mathrm{PhD}$ student, and to a lesser extent on me as a supervisor-I had some insight into why it had happened. Most readers would not have had any inside information and hence been unable to see beyond the story as presented.

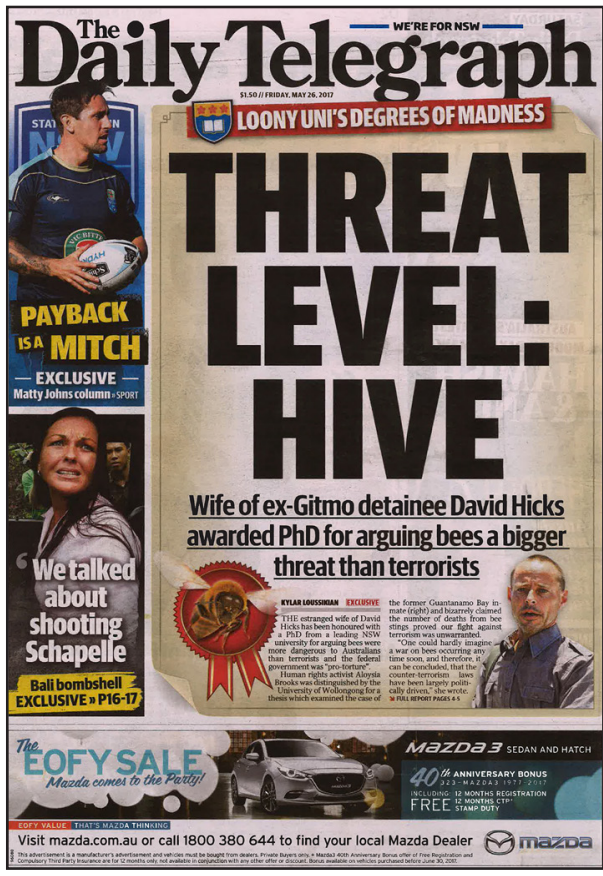

Figure 1: The Daily Telegraph front page, triggered by a doctoral thesis, 26 May 2017. My aim in this article is to analyse this particular story in order to show that a beat-up, though seemingly random in its target, can reflect the predilections of the outlet and the journalist. To begin, I describe the nature of a beat-up and its connection with related concepts such as sensationalist media coverage. Then I look at three contexts for the story about Brooks' thesis: the venue, namely the Daily Telegraph; the journalist who wrote the story; and the content of the story. What is striking about this particular example of a beat-up is that in attacking Brooks' thesis, it exemplifies exactly what she documented in her research. In conclusion, I comment on the value of studying beat-ups.

\section{Media beat-ups}

The concept of 'beat-up' seems not to have been defined in the scholarly literature. According to YourDictionary, a beat-up is 'an artificially or disingenuously manufactured alarm or outcry, especially one agitated by or through the media.' This term is used in Australia, Britain and New Zealand. Because 'beat-up' is not commonly used elsewhere, it is worthwhile saying a bit more about the concept.

In the context of the media, a beat-up is a story that, by conventional journalistic standards, does not deserve to be published because it is unverified, grossly exaggerated and/or knowingly false. Typical features of beat-ups include presenting manufactured claims, giving otherwise unexceptional information 


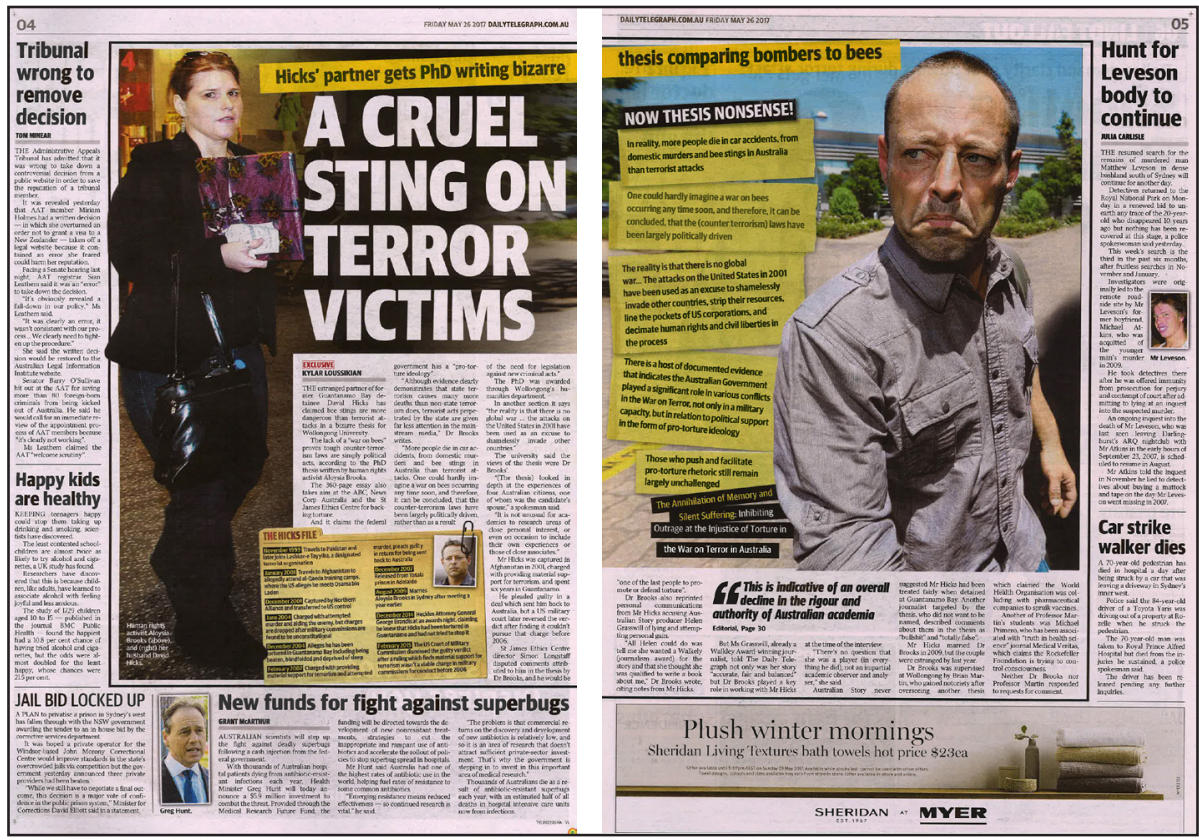

Figure 2: The inside spread on pages 4 and 5 in the Daily Telegraph, 26 May 2017.

an exaggerated importance, highlighting facts taken out of context, presenting highly misleading portrayals and using weak or dubious sources. For example, a story might portray a few incidents as revealing a dangerous trend. There might be lurid reports about break-ins in a particular suburb, indicating a crime wave, even though there has been no increase in break-ins and this particular suburb has no more crime than average.

It is useful to describe beat-ups in the context of other terms relating to journalistic practices. News and current affairs can be distinguished from other facets of the media, for example advertising, entertainment, travel and reviews. News reporting is governed by a set of implicit rules about topics and writing style, usually following the priorities dictated by news values (Bednarek \& Caple, 2012; Brighton \& Foy, 2007). Beat-ups can be reported as news but can also occur in other areas of the media. It might be argued that some advertising, for example for miracle cures, falls in the category of a beat-up.

Another relevant concept is sensationalism, which refers to stories aiming to attract readers by dramatic and lurid headlines, tantalising titbits of information, and emphasis on crime and scandal. Some outlets specialise in reporting scandals and outrageous exposés, notoriously the US magazine The National Enquirer, and many of its stories could be considered beat-ups. Historically in the US, what was called 'yellow journalism' was characterised by sensationalism (Campbell, 2001). 
Sensationalism is standard in reporting devoted to scandal and gossip, and conversely scandal relies on publicity (Adut, 2008; Entman, 2012). Stories about celebrities, as seen for example in headlines in Australian magazines such as Women's Day and Who, take an everyday sort of event and turn it into something sensational. A celebrity might be overweight, pregnant, dating someone new, ill or revealed in photographs, and this is treated as a big story. The increasing media coverage of the private lives of public figures has been called tabloidisation (Sparks \& Tulloch, 2000). Such stories are most obviously beat-ups when there is no basis for the claims made, as when a celebrity is not actually seeing a new person and is bemused to read about it.

The phenomenon of celebrity gossip stories - especially when celebrities, such as the Kardashians, are primarily known for being well-known rather than any notable accomplishments - shows that the concept of beat-up may apply to entire genres of reporting. A story is manufactured out of something that is incorrect or banal and presented to audiences as exciting.

There is a connection between beat-ups and what are called 'moral panics,' which are alarms about threats to the moral order (Cohen, 2002). In a typical sequence, something is defined as a threat to social values, the media provide a convenient portrayal of the threat, generating public concern, to which authorities respond (Thompson 1998, p. 8). A beat-up can be part of a convenient media portrayal of someone or something, such as drug use, criminal gangs, transsexuals, or political correctness, as a threat to social values. A prominent example is terrorism: someone arrested for possibly planning an attack receives saturation media coverage whereas cases of domestic violence, which kill far more people, seldom receive a mention. In a 'political moral panic' (Shafir \& Schairer, 2013), the government defines terrorism as a threat to the integrity of society and the mass media follow the government's agenda. However, beat-ups do not have to be part of an ongoing moral panic: they can be singular stories without much connection to a campaign or current issue.

Relating to the role of the media in moral panics is the concept of 'mediahype' (Vasterman, 2005), in which reporting on a topic triggers more investigation and reporting on the topic. In essence, media coverage becomes self-reinforcing. Waves of media-hype can involve beat-up stories, but not necessarily so.

Another relevant category is 'attack journalism', referring to stories that denigrate particular individuals or groups. For example, for years Sydney University peace studies academic Jake Lynch has been targeted in some media outlets over his support for the Boycott, Divestment, Sanctions movement (Blizzard, 2017; Higgins, 2013). David Robie and his colleague Ingrid Leary, when they worked in the University of the South Pacific's Journalism Programme, were the targets of a hostile campaign by some Fiji journalists over investigative journalism (Robie, 2003). Attack journalism is common in political reporting (Sabato, 1991) and 
in various other areas. Some media outlets specialise in making attacks. Hager (2014), who obtained a large number of leaked documents about New Zealand political shenanigans, provides a particularly revealing account of the operation of attack journalism in politics. A notorious and extreme example is certain media in Rwanda, for example the radio network RTLM (Radio Télévision Libre des Milles Collines), prior to and during the 1994 genocide. RTLM, covertly serving government agendas, broadcast hate against Tutsi, including many lies. It denounced individuals by name, putting their lives at risk. As the genocide proceeded, RTLM provided specific guidance for killing activities (Article 19, 1996). There is an overlap between attack journalism and beat-ups, but they are not identical. A beat-up can be about an innocuous matter and does not have to be personal - for example, a story about a change in house prices - and attack journalism can be accurate. There is also an overlap between attack journalism and reporting of scandal and gossip. In political attack journalism, the private foibles of politicians, having no direct connection to their professional performance, become the target for exposure and denigration.

My focus here is on beat-ups in the attack category. Typically, these serve to stigmatise the target, which can be an individual or category of people, or particular activities. A characteristic attack beat-up highlights a few facts taken out of context that serve to give a misleading picture.

A deeper critique of the media would lead to the suggestion that much regular news reporting is a type of beat-up. For example, Western media coverage of armed conflicts typically concentrates on a few current issues, such as North Korean nuclear capabilities, with some conflicts such as Israel-Palestine being perennial favourites. Meanwhile, many more deadly conflicts receive little or no coverage, such as the wars in the Congo that killed perhaps five million people (Hawkins, 2008).

However, to call the majority of media coverage a systematic set of beat-ups is not illuminating and mainly serves to draw attention to well-canvassed shortcomings of the mass media, for little advantage. It makes more sense to reserve the term beat-up for particular cases of journalistic practice, distinguished by their contrast with reporting norms. Characteristic types of beat-ups include alarm, attack, amazement, human interest and humour. Because any of these may sometimes occur in quality journalism, there is no sharp separation between regular stories and beat-ups. A beat-up is towards one end of a spectrum of practices.

Phillips (2015) examines the activities of trolls - individuals who transgress the usual boundaries of good taste and proper behaviour. For example, in so-called RIP trolling, trolls go the Facebook pages of recently deceased youths and make nasty comments about them. Phillips makes the point that trolling often involves behaviours that mimic the worst tendencies of sensationalist mainstream media. When a young, white attractive female dies, this can become a significant media 
story, sometimes involving reporters intrusively seeking comments from and news footage of grieving relatives. Trolls, according to Phillips, simply go one step further in this sort of ghoulish obsession with particular deaths. Meanwhile, other deaths go unreported.

In summary, the concept of a media beat-up points to a particular type of coverage, and has overlaps with other concepts. Some, but not all, beat-ups are in news coverage. They usually involve sensationalism, but there are also stories of scandal and gossip that are not beat-ups. Some, but far from all, beat-ups contribute to moral panics and media-hype. Some, but not all, beat-ups are part of attack journalism.

My interest here is in showing how it is possible to go about trying to understand unanticipated beat-ups, ones that are not part of an ongoing issue. The sudden occurrence of a beat-up story may appear random, especially when it has no precedent or follow-up. My aim here is to illustrate how even an apparently idiosyncratic story can be understood as part of a wider pattern.

In the following sections I examine three aspects of Kylar Loussikian's story in the Daily Telegraph about Aloysia Brooks' thesis: the outlet, the journalist and the political assumptions underlying the story. None of these determine the selection or content of the story, but they provide constraints or influences. A beat-up might be a random choice in some ways, but selected from a lottery with a restricted set of winners.

In undertaking this analysis, I started with an understanding of Brooks' thesis, and familiarity with relevant portions of Loussikian's reporting. I looked at coverage of related matters in the Daily Telegraph and other media, and compared the content of Loussikian's story with Brooks' thesis. I sent a draft of this paper to both Loussikian and the Daily Telegraph inviting comment but received no response.

\section{The outlet}

The Daily Telegraph, sometimes referred to as the Tele, is a newspaper published six days per week with its stablemate, the Sunday Telegraph, on the seventh. Published in Sydney, Australia's largest city, it is distributed primarily in the state of New South Wales. It is the highest circulation daily in Sydney and second highest in the country.

The newspaper is owned by Rupert Murdoch's News Corp Australia. Murdoch initially built his media empire in Australian newspapers before expanding worldwide and becoming a US citizen (Tiffen, 2014). The Tele is tabloid in format and in style: it is a downmarket newspaper aimed at a working class readership. Its primary newspaper competitor is the Sydney Morning Herald, often characterised as a quality daily, and with a more middle-class and progressive readership.

The political slant in the Tele is conservative. It is anti-union and anti-Labor Party, sometimes aggressively so. This is most apparent in the pieces by regular 
columnists Tim Blair, Andrew Bolt, Miranda Devine and Joe Hildebrand, who adopt stridently conservative positions on a range of issues. Quite a few frontpage stories target disadvantaged groups such as welfare cheats and refugees.

Universities, especially their humanities faculties, are occasional targets in Telegraph stories, as part of hostility to allegedly left-wing bias. For example, in 2018 a Telegraph journalist covertly attended classes at universities in Sydney and wrote a story decrying in-class comments by three named academics, presenting them as exemplifying 'a culture of cotton wool and political correctness' (Harris, 2018).

The Telegraph, along with much of the rest of the Australian media, has enthusiastically supported the government's war-on-terror agenda, so it runs breathless stories about terrorist threats and supports repressive anti-terrorist legislation. This provides a receptive context for a beat-up about a passage in a $\mathrm{PhD}$ thesis about the war on terror.

Aloysia Brooks, when she did her doctorate at the University of Wollongong, had been a human rights campaigner for a decade. She previously had been married to David Hicks, an Australian who was imprisoned in Guantanamo Bay and tortured there before being released in a plea bargain.

In the years after 9/11, Hicks was a divisive figure in Australian politics. As one of two Australian citizens imprisoned at Guantanamo, the Australian government treated him as a terrorist. He became a whipping boy for defenders of a tough, militaristic orientation to terrorism. However, others saw him as a naïve, misguided individual who went to Afghanistan following his acquired Muslim convictions but who was not involved in terrorism. Opponents of torture and of the excesses of the war on terror saw Hicks as a victim. His imprisonment without trial became symbolic of problems with the war on terror, and pressure increased on the Australian government to do something. Prior to the 2007 national election, the government negotiated with US authorities to release Hicks and have him serve a remaining year in an Australian prison. This alleviated the political pressure on the government. Subsequently, the US government exonerated Hicks of all crimes (Hicks, 2010; Joseph, 2016).

For conservative commentators though, Hicks continued to be seen as a traitor, as a symbol of the enemy at home in the war on terror. Castigating Hicks was part of supporting the Australian government's war-on-terror agenda, and News Corp media have been enthusiastic in that support. In contrast, in the Telegraph's rival daily newspaper, the Sydney Morning Herald, backing of the government's anti-terror agenda has been strong but more qualified, with occasional voices of dissent (Gittins, 2017).

From the beginning (Dunn, 2001), most Telegraph reporting about Hicks was hostile to him. The context for the 2017 story about Brooks' thesis is suggested by commentary about Hicks in the preceding few years in the Telegraph. 
After Hicks confronted Attorney-General George Brandis at a talk given by Brandis, Piers Akerman (2014) criticised Hicks and criticised the ABC for reporting on the confrontation, saying the $\mathrm{ABC}$ 'is once again showing it's [sic] loony-Left bias to real good news'. Miranda Devine (2014) complained about Hicks 'playing the victim, and being applauded by leftist stooges like [Greens senator] Sarah Hanson-Young.' In early 2015, after the US Court of Military Commission Review exonerated Hicks, dismissing his guilty plea, Telegraph columnists continued to condemn him. Devine (2015) wrote, 'Far from being owed an apology and compensation from the Australian government, one-time al-Qaeda pin-up boy David Hicks should be apologising to us.'

Akerman (2015) said: 'Hicks is still guilty in the court of public opinion.' Political reporter Daniel Meers (2015) wrote about politicians who condemned Labor Party leader Bill Shorten's comment that Hicks had suffered an injustice. When Hicks was charged with domestic violence against a new partner, this was the basis for several Telegraph stories (e.g. Dowdell \& Fewster, 2016). In recent years, the one exception to the Telegraph's otherwise uniform defence of the Australian government in relation to torture of prisoners at Guantanamo Bay was a long story by Paul Toohey (2014) telling about torture methods used.

The Telegraph's enthusiastic support for the war on terror and critical commentary on Hicks provided receptive context for a story about Brooks' thesis. The context in which it was published and The Telegraph's previous record suggest that the story provided an opportunity to condemn Hicks via his former wife's supposedly silly comparison with a war on bees.

\section{The journalist}

The story was written by Kylar Loussikian, relatively new to The Telegraph. For the previous few years he had reported for The Australian, a national daily also owned by News Corp Australia and with roughly the same political orientation, though a far more sober style.

Loussikian in 2015 wrote several stories about issues involving conflicts of interest among members of the governing body of the University of Wollongong (UOW) (Loussikian, 2015a, b). In January 2016, he wrote a front-page story in The Australian about Judy Wilyman, a recent doctoral graduate from the University of Wollongong. I was Wilyman's principal supervisor. Her thesis was a critical examination of the Australian government's vaccination policy, and for several years during her candidature she came under attack from members of a pro-vaccination citizens' group, Stop the Australian Vaccination Network (SAVN). Loussikian's article, published on 13 January 2016, attacked Wilyman's thesis, Wilyman, me as her supervisor and UOW for granting her a PhD (Loussikian, 2016). As I have documented elsewhere (Martin, 2016), Loussikian's article condemned Wilyman's thesis on the basis of quotes taken out of context, alleged 
that the thesis promoted a conspiracy theory, and used guilt by association.

Loussikian's 13 January 2016 article, published just two days after Wilyman's thesis was available online, unleashed a huge attack, including hundreds of blog comments, freedom-of-information requests to obtain the names of the thesis examiners, a petition signed by over 2,000 people, and calls for her thesis to be revoked. Loussikian followed up with numerous further stories during the year about the thesis and the controversy his reporting had triggered. UOW leaders took a strong stand in support of academic freedom and weathered the onslaught (Martin, 2017).

The point here is that Loussikian had a track record of writing stories critical of UOW and critical of my doctoral students. The tone of his 26 May 2017 story was set by the banner above the main front-page headline: 'Loony uni's degrees of madness'. Towards the conclusion of his article, Loussikian commented about two of my other PhD students.

Dr Brooks was supervised at Wollongong by Brian Martin, who gained notoriety after overseeing another thesis which claimed the World Health Organisation was colluding with pharmaceutical companies to spruik vaccines.

Another of Professor Martin's students was Michael Primero, who has been associated with 'truth in health science' journal Medical Veritas, which claims the Rockefeller Foundation is trying to control consciousness.

Loussikian does not name Judy Wilyman, nor does he mention that the "notoriety' he ascribes to me was triggered by his own stories in The Australian, nor that I comprehensively replied to his story and its misleading claim about collusion. Loussikian does name another student of mine, Michael Primero-who began his $\mathrm{PhD}$ with me in the 1990s but discontinued - and uses guilt by association to discredit him and me. Primero's association with Medical Veritas was separate from his $\mathrm{PhD}$. The journal does not make any claim about controlling consciousness; rather, a 2015 article in the journal made that claim.

Loussikian initially brought up Primero being my student—one of $30 \mathrm{PhD}$ students for whom I have been principal supervisor-in his articles attacking Wilyman's thesis. Thus, prior to his story about Brooks' thesis, Loussikian had previously targeted the University of Wollongong, me and two of my PhD students. In this context, the story about Brooks' thesis was not random.

\section{The thesis and the story}

Brooks' thesis is titled 'The annihilation of memory and silent suffering: Inhibiting outrage at the injustice of torture in the War on Terror in Australia' (Brooks, 2016). In 2017, Brooks received the Professor Jim Hagan Memorial Prize, awarded annually to the PhD student with the best thesis completed in 
the previous year in the School of Humanities and Social Inquiry at the University of Wollongong.

The contents of the thesis are clearly spelled out in its abstract.

The War on Terror, initiated by the US Government under George W. Bush, reintroduced torture as an overt tool of the state. The Australian Government was heavily implicated in colluding and covering up the US torture program. Drawing on a model of outrage management, newspaper articles from 2002-2012 reveal extensive evidence that government officials, their agents, and the media, utilised methods that served to reduce outrage over the use of torture in the War on Terror. These tactics not only inhibited outrage, but promoted acceptance of torture as a legitimate security tool in the post $9 / 11$ era.

There is significant evidence that government officials, and a mostly compliant media, engaged in cover-up, either by omitting information, destroying evidence of torture, or failing to call into question statements made by US or Australian officials. There is extensive evidence of dehumanising or devaluing the survivors/victims and their experience including denigrating them as liars, casting them as unreliable sources, or, alternatively, attacking their personal character. Evidence extends to the reinterpretation of events and the way in which language was used to shift focus off torture to concerns about innocence or guilt. Rather than naming torture for what it is, terminology such as 'abuse' or 'mistreatment' was commonly used throughout the decade of analysis.

The use of official channels to minimise outrage was apparent through the use of official spokespeople, or investigations that only gave the appearance of justice. There was also extensive evidence of the use of intimidation towards whistleblowers and torture survivors in order to prevent them from telling their stories. Those involved in torture were rewarded, commonly through promotion.

These tactics were enabled by networks of individuals, organisations and institutions that carry out ideological, economic, practical or political functions to support the facilitation and cover-up of state-inflicted torture. These networks include shallow governments that deploy misleading political rhetoric related to torture and terrorism, the increased role of militarism and covert operations, and the expansion of the surveillance state. Therefore, challenging torture in the War on Terror requires broader structural and societal change to eliminate the pillars of support for torture. Removing the structural support for torture may require the dismantling of the entire network through a process of nonviolent resistance. (Brooks, 2016, pp. 3-4)

Her thesis addresses torture in the war on terror using a model of outrage management, which is a set of techniques commonly used by powerful perpetrators 
to reduce public outrage over injustice. The five techniques are: cover-up of information, devaluation of targets, reinterpretation of actions, official channels that give only an appearance of justice, and intimidation (Martin, 2007). The striking aspect of Loussikian's article is that it uses several of these very methods, without any self-reflection.

In relation to cover-up, Loussikian's article gives little attention to evidence about the torture of David Hicks or to the Australian government's role in hiding this evidence. In relation to devaluation, much of the article comes across as implied criticism of Hicks, continuing a long tradition in the Telegraph and much of the Australian media. A central feature of Brooks' thesis is an analysis of the subservient role of the Australian media in relation to Australian and US government agendas in the war on terror, which included demonising the prisoners at Guantanamo Bay (e.g., 'the worst of the worst'). Loussikian's article is hostile to Hicks, thus exemplifying Brooks' argument.

In relation to reinterpretation, Brooks' thesis addressed the way 'language was used to shift focus off torture to concerns about innocence or guilt.' Loussikian's article does exactly this: it doesn't address torture in the war on terror, but instead concentrates on Hicks' activities.

In her thesis, Brooks wrote about the intimidation of torture survivors and of whistleblowers. Loussikian's story could be seen as a form of intimidation: a full-scale mass-media attack on the work of a recent graduate who had the temerity to criticise media coverage of torture in the war on terror. By pointing to alleged shortcomings in the thesis, Loussikian's story suggests the potential for violations of university procedures, something quite threatening to the reputation of a scholar (no such violations were ever verified). It requires courage to challenge the dominant narrative on torture and terrorism and to question the reliability and veracity of media treatments, because the mass media have large resources to disseminate their viewpoints and condemn critics.

So what does Loussikian's article actually cover? It picks a few passages out of the thesis, without a suggestion that these are representative or especially significant in relation to the overall argument of the thesis, and either holds them up to ridicule - taken to be self-evident, as in the case of the bee comparisonor quotes individuals who said their views had been misrepresented. This is as close as the article comes to providing any official endorsement to the alleged shortcomings of the thesis. Loussikian is critical of the thesis but cites no authorities in the field to say it is substandard or that her $\mathrm{PhD}$ was inappropriately granted. Loussikian's article was supported by an editorial (Figure 3) and a Warren cartoon (Figure 4).

Loussikian's ridicule of Brooks' sentences about bees and terrorism can be understood as based on an implicit acceptance of the assumptions underlying the war on terror, leading to an unreflective rejection of any comparison suggesting 
that the dangers from terrorism have been inflated. The three sentences on page 147 of her thesis about bees and terrorism were at the end of an examination of the Australian government's harsh anti-terror laws, in which she noted that they had been criticised in the 2011 annual report of the Independent National Security Legislation Monitor (Walker, 2011). As she noted, this report compared the number of Australians killed by terrorism with the much larger number of murders at home by family members. As well as bees, similar comparisons could readily be made with domestic violence, tractor accidents, falling out of bed, drowning in swimming pools and numerous other activities, each of which kills many more people in Australia than terrorism.

There is ample scholarly commentary pointing out that the war on terror has involved a gross exaggeration of the dangers of non-state terrorism (e.g., Mueller, 2006; Zulaika, 2014), while meanwhile state terrorism is ignored (e.g. Gareau, 2004). Even further off the media radar is the role of the mass media in enabling terrorist communication to audiences (Nacos, 2002; Schmid \& de

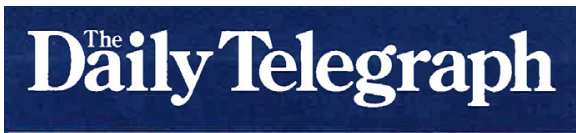
PhD stings as standards slip

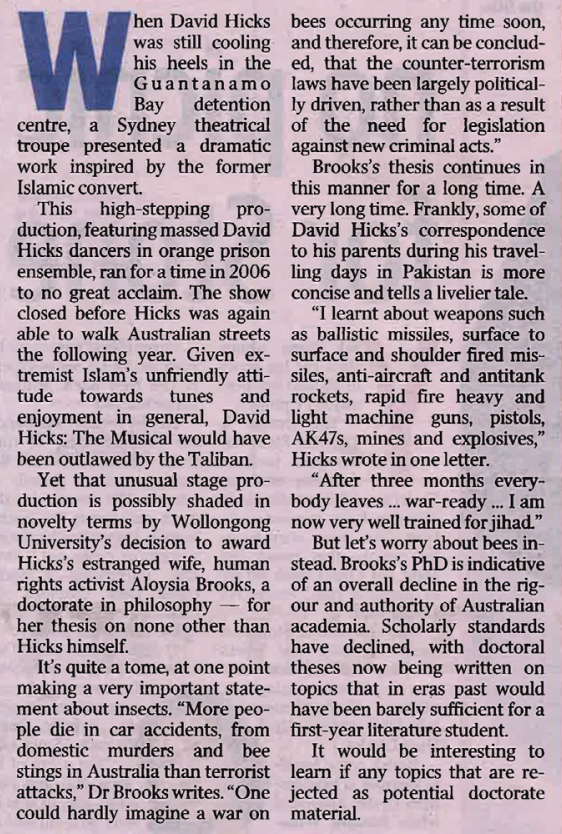

Figure 3: The Daily Telegraph editorial 'PhD stings as standards slip', page 30, 26 May 2017. Graaf, 1982; Tuman, 2003).

Curiously, a few years previously there had been a story in the British newspaper The Telegraph comparing deaths from terrorism and insect stings (Beckford, 2012). The angle was the opposite of Loussikian's. The Telegraph considered it newsworthy that David Anderson, the Independent Reviewer of Terrorism Legislation, had reported that British deaths from terrorism were far less than from numerous everyday causes. The story in The Telegraph quoted this passage from Anderson's report:

During the 21st century, terrorism has been an insignificant cause of mortality in the United Kingdom. The annualised average of five deaths caused by terrorism in England and Wales over this period compares with total accidental deaths in 2010 of 17,201, including 123 cyclists killed in 
traffic accidents, 102 personnel killed in Afghanistan, 29 people drowned in the bathtub and five killed by stings from hornets, wasps and bees. (Anderson, 2012, p. 27)

Any piece of research is potentially vulnerable to attack by using Loussikian's techniques: pick a few passages out of context and hold them up to ridicule, allege shortcomings and quote critics. For most students, an attack like this would definitely be intimidating, and the possibility of being denigrated in the mass media would be enough to discourage some students from tackling a controversial topic. The saving grace in the case of Loussikian's article is that his treatment was so unbalanced, and in a publication noted for its partisan attacks, that it had little credibility among informed audiences.

In summary, Loussikian's story gave scant attention to the substance of Brooks' thesis. Instead, the methods used in the story exemplified the methods that Brooks had documented were commonly used in the Australian mass media when reporting torture in the war on terror.

Loussikian's article was a beat-up in that it turned a small matter-a noncentral passage in a $\mathrm{PhD}$ thesis - into a front-page story. It was an unusual beatup in that it actually illustrated the very techniques documented in the thesis it was attacking.

In the previous paragraphs, I started with Brooks' thesis and have commented on how Loussikian's article did not address its central contentions. Another approach is to analyse the text of Loussikian's article, seeing whether it fits the characteristics of a beat-up and of attack journalism. In a separate treatment (Martin, 2018), I have assessed all the text in Loussikian's article both for characteristic features of a beat-up and for characteristic features of attack journalism. Of the typical features of a beat-up mentioned earlier, three are prevalent in Loussikian's story: giving otherwise unexceptional information an exaggerated importance; highlighting facts taken out of context; and presenting highly misleading portrayals. More generally, the story:

- takes quotes out of context and magnifies their importance;

- makes no attempt to present the argument in the thesis or to put it in context; and

- provides no independent support for why this topic is noteworthy.

In relation to attack journalism, Loussikian's story includes derogatory language (e.g., 'bizarre thesis'), guilt by association (especially by highlighting Brooks' connection with David Hicks), and humorous dismissal (reference to a war on bees).

\section{Conclusion}

The term 'beat-up' is used occasionally in everyday conversation, but as a genre of journalism it seems under-studied, perhaps because it is simply one type 
of sensationalism, which itself is understudied. Yet for those who are affected, whether as readers or as subjects of stories, beat-ups can be a serious matter and are worth understanding.

Many of those at the coalface of media productionjournalists, editors, headline writers, proprietors - might be able to provide insider accounts of how sensationalist coverage

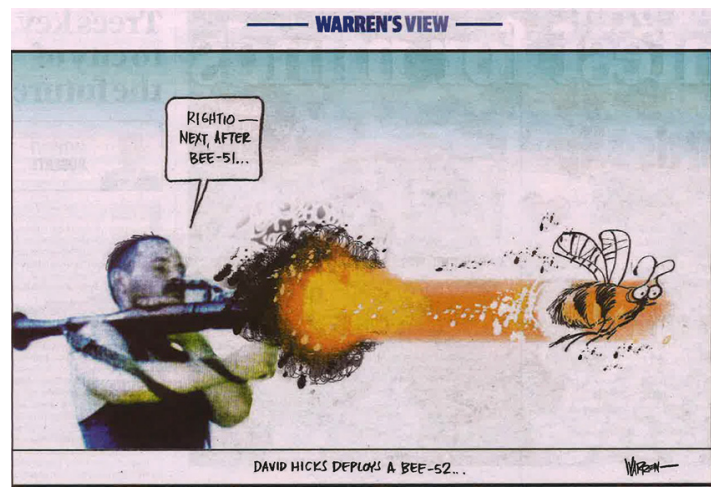

Figure 4: The Warren 'bee blast' cartoon in the Daily Telegraph, page 31, 26 May 2017.

is crafted, but tell-all accounts are uncommon. For nearly all stories as they appear, there are no insider accounts, so readers must rely on other means of interpretation.

I analysed a particular story. I have categorised it as a beat-up and as a particular type of beat-up, an example of attack journalism. It also can be described as sensationalism, and it draws on the ongoing political moral panic about nonstate terrorism. Most readers would not have any particular knowledge about the matters addressed in the story. Despite lacking inside knowledge, it is possible to analyse such stories. Three ways were illustrated here: analysing the media outlet's track record, analysing the journalist's track record, and analysing the story. Loussikian's story about Aloysia Brooks' doctoral thesis is compatible with the war-on-terror perspective commonly adopted in the News Corp newspaper the Daily Telegraph. The story denigrates David Hicks, who had long been an object of contempt by Daily Telegraph columnists. Finally, the story has several of the same targets as in Loussikian's previous stories, and uses the same sorts of attack techniques.

However, patterns in media coverage do not provide definitive evidence that a particular story is a beat-up. For this, close familiarity with the subject matter is vital. However, few readers have such familiarity. For those who lack knowledge of the topic, few make any attempt to obtain additional and independent information. In the aftermath of Loussikian's story, not a single person contacted me for more information. Nor was there a spike in downloads of Brooks' thesis, although its title was given in the story and would have been easy to find on the web. This suggests that few readers made an attempt to independently assess the story.

This analysis of Loussikian's story shows some ways to proceed in the study of beat-ups. There is more to be learned, including whether there are effective ways to counter them. 


\section{References}

Adut, A. (2008). On scandal: Moral disturbances in society, politics, and art. New York, NY: Cambridge University Press.

Akerman, P. (2014, December 12). ABC wasting our time on a loudmouth. Daily Telegraph, p. 72.

Akerman, P. (2015, February 20). The difference between 'innocent' and innocent. Daily Telegraph, p. 36.

Anderson, D. (2012). The Terrorism Acts in 2011: Report of the Independent Reviewer on the Operation of the Terrorism Act 2000 and Part 1 of the Terrorism Act 2006. London, UK: The Stationery Office.

Article 19 (1996). Broadcasting genocide: Censorship, propaganda and state-sponsored violence in Rwanda 1990-1994. London, UK: Article 19.

Beckford, M. (2012, June 28). Bee stings killed as many in UK as terrorists, says watchdog. The Telegraph. Retrieved 5 September 2018, from www.telegraph.co.uk/news/ uknews/terrorism-in-the-uk/9359763/Bee-stings-killed-as-many-in-UK-as-terroristssays-watchdog.html.

Bednarek, M., \& Caple, H. (2012). News discourse. London: Continuum.

Blizzard, E. (2017). Peace journalism in Palestine's BDS campaign. Peace Review 29, 467-474.

Bolt, A. (2017, May 26). David Hicks' estranged wife gets PhD for conspiracy theory. Herald Sun. Retrieved 6 September 2018, from www.heraldsun.com.au/blogs/andrewbolt/david-hicks-estranged-wife-gets-phd-for-conspiracy-theory/news-story/886f $2 \mathrm{cb}$ $67 \mathrm{fa} 2 \mathrm{bd} 255 \mathrm{eac} 2 \mathrm{a} 51 \mathrm{c} 20 \mathrm{afdbc}$

Brighton, P., \& Foy, D. (2007). News values. Los Angeles, CA: Sage.

Brooks, A. (2016). The annihilation of memory and silent suffering: Inhibiting outrage at the injustice of torture in the War on Terror in Australia. Unpublished doctoral thesis, University of Wollongong, Australia. Retrieved 4 September 2018, from http:// ro.uow.edu.au/theses/4865/.

Campbell, W. J. (2001). Yellow journalism: Puncturing the myths, defining the legacies. Westport, CT: Praeger.

Cohen, S. (2002). Folk devils and moral panics 3rd ed. London, UK: Routledge.

Devine, M. (2014, December 14). Whingeing Hicks has a lot to say sorry for. Daily Telegraph, p. 17.

Devine, M. (2015, February 22). Hicks should say he's sorry. Daily Telegraph, p. 17.

Dowdell, A., \& Fewster, S. (2016, November 22). Terror accused on bash charge. Daily Telegraph, p. 6.

Dunn, M. (2001, December 13). My son has betrayed us-he's a terrorist, says his father - a traitor to his country. Daily Telegraph, p. 1.

Eddie, R. (2017, May 26). Un-bee-lievable! Wife of Guantanamo Bay inmate David Hicks' awarded PhD_for claiming BEES are more dangerous to Australians than TERRORISTS. Daily Mail Australia. Retrieved 6 September 2018, from http://www. dailymail.co.uk/news/article-4543220/David-Hicks-wife-PhD-bees-terrorism.html

Entman, R. M. (2012). Scandal and silence: Media responses to presidential misconduct. Cambridge, UK: Polity.

Gareau, F. H. (2004). State terrorism and the United States: From counterinsurgency to the war on terror. London, UK: Zed Books.

Gittins, R. (2017, July 26). The biggest scam and why we buy it. Sydney Morning Herald, pp. $20-21$.

Hager, N. (2014). Dirty politics: How attack politics is poisoning New Zealand's political environment. Nelson, NZ: Craig Potton. 
Harris, C. (2018, August 8). Degrees of hilarity. Daily Telegraph, pp. 4-5.

Hawkins, V. (2008). Stealth conflicts: How the world's worst violence is ignored. Aldershot, UK: Ashgate.

Hicks, D. (2010). Guantanamo: My journey. Sydney, NSW: Random House Australia.

Higgins, E. (2013, December 28). Lynch like 'publican denying blacks, Jews.' The Australian, p. 2.

Joseph, S. (2016, February 22). Australia found to have breached the human rights of David Hicks. The Conversation. Retrieved 4 September 2018, from https://theconversation.com/australia-found-to-have-breached-the-human-rights-of-david-hicks-55120.

Loussikian, K. (2015a, March 25). Row over UOW donations to Libs. The Australian, p. 31.

Loussikian, K. (2015b, June 3). Cash to political parties queried. The Australian, p. 33.

Loussikian, K. (2016, January 13). Uni accepts thesis on vaccine 'conspiracy'. The Australian, pp. 1, 4.

Loussikian, K. (2017, May 26). Threat level: hive. Daily Telegraph, pp. 1, 4-5.

Martin, B. (2007). Justice ignited: The dynamics of backfire. Lanham, MD: Rowman \& Littlefield.

Martin, B. (2016, March 3). News with a negative frame: a vaccination case study. Retrieved 4 September 2018, from http://www.bmartin.cc/pubs/16Loussikian.html.

Martin, B. (2017). Defending university integrity. International Journal for Educational Integrity 13(1), 1-14.

Martin, B. (2018). A cruel sting on a PhD graduate: Analysis of a Daily Telegraph article. Retrieved 7 September 2018, from http://www.bmartin.cc/pubs/18Loussikian.pdf.

Meers, D. (2015, February 20). Anger as Shorten claims 'injustice' for Hicks. Daily Telegraph, p. 1.

Mueller, J. (2006). Overblown: How politicians and the terrorism industry inflate national security threats, and why we believe them. New York, NY: Free Press.

Nacos, B. L. (2002). Mass-mediated terrorism: The central role of the media in terrorism and counterterrorism. Lanham, MD: Rowman \& Littlefield.

Phillips, W. (2015). This is why we can't have nice things: Mapping the relationship between online trolling and mainstream culture. Cambridge, MA: MIT Press.

Robie, D. (2003). Cyberspace democracy: Freedom of speech dilemmas in Pacific journalism education. UTS Law Review 5, 131-149.

Sabato, L. J. (1991). Feeding frenzy: How attack journalism has transformed American politics. New York, NY: Free Press.

Schmid, A. P., \& de Graaf, J. (1982). Violence as communication: Insurgent terrorism and the western news media. London, UK: Sage.

Shafir, G., \& Schairer, C. E. (2013). The war on terror as political moral panic. In G. Shafir, E. Meade, \& W. J. Aceves (Eds.), Lessons and legacies of the War on Terror: From moral panics to permanent war (pp. 9-46). London, UK: Taylor \& Francis.

Sparks, C., \& Tulloch, J. (Eds.) (2000). Tabloid tales: Global debates over media standards. Lanham, MD: Rowman \& Littlefield.

Thompson, K. (1998). Moral panics. London: Routledge, UK.

Tiffen, R. (2014). Rupert Murdoch: A reassessment. Sydney, NSW: NewSouth.

Toohey, P. (2014, December 13). CIA's catalogue of dirty deeds. Daily Telegraph, p. 71.

Tuman, J. S. (2003). Communicating terror: The rhetorical dimensions of terrorism. Thousand Oaks, CA: Sage.

Vasterman, P. L. M. (2005). Media-hype: Self-reinforcing news waves, journalistic standards and the construction of social problems. European Journal of Communication, 20(4), 508-530. 
Walker, B. (2011). Independent National Security Legislation Monitor: Annual report (Department of the Prime Minister and Cabinet, 16 December). Canberra, ACT: Commonwealth of Australia.

Zulaika, J. (2014). Terrorism: The self-fulfilling prophecy. Chicago, IL: University of Chicago Press.

The author thanks Richard Jackson, Stuart Rees, David Robie, Steve Wright and three anonymous referees for valuable comments on earlier versions of this paper.

Dr Brian Martin is emeritus professor of social sciences at the University of Wollongong, Australia. He has written on nonviolent action, whistleblowing, scientific controversies, information politics, education and other topics.

bmartin@uow.edu.au

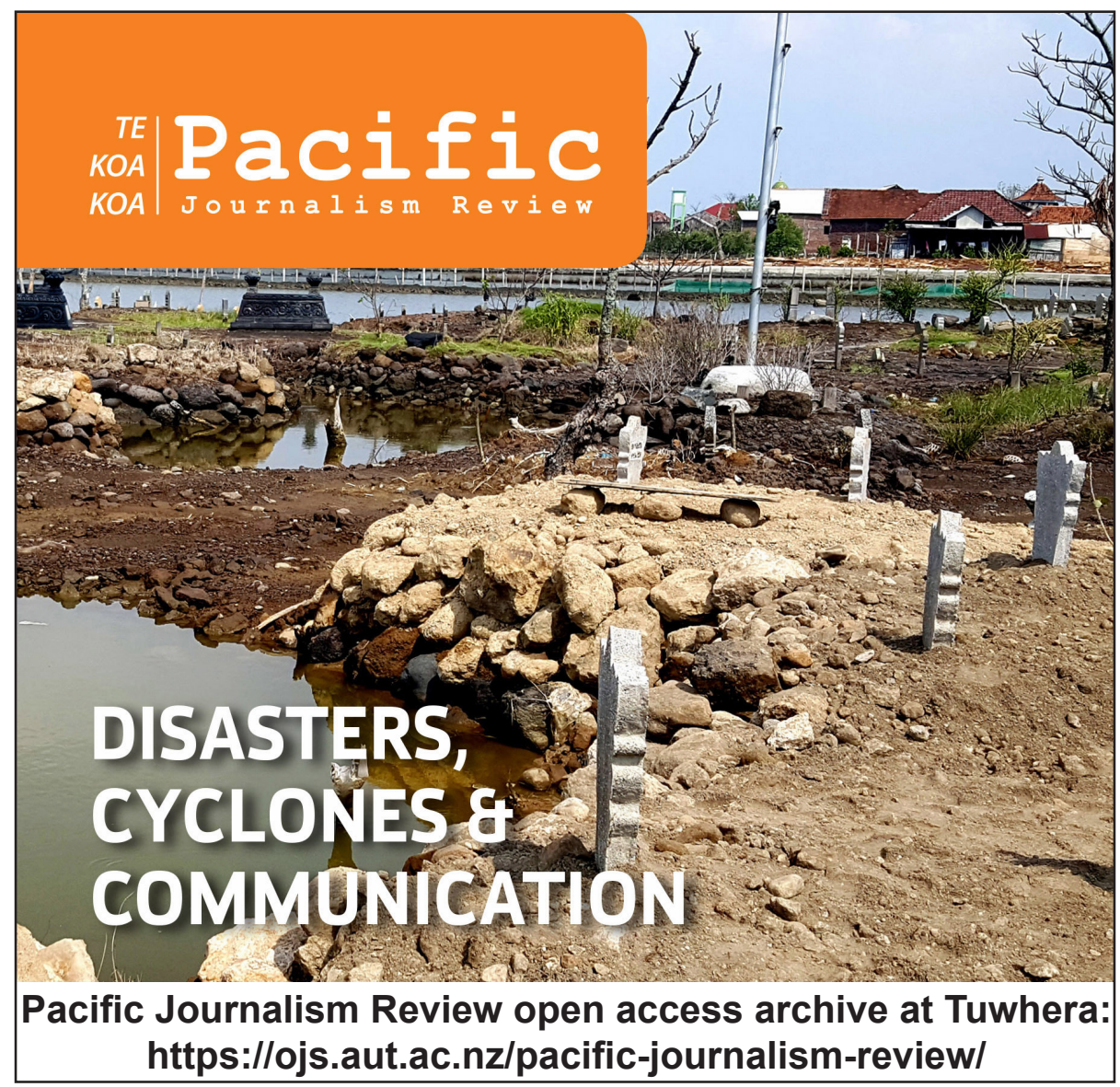

